\title{
I will never see a full moon the same
}

\section{Estelle Viaud-Murat ${ }^{\mathrm{a}}$}

${ }^{a} \mathrm{MD}(\mathrm{c})$, Wright State University, Boonshoft School of Medicine, Dayton, OH, USA.

I will never see a full moon the same

Since the night I stepped out

In the dark, looked up to the moon and

Heard the cries of a mother who just lost her son.

The African moon, so full and so proud, seemed too bright for such a somber night.

And my empty hands, which this son once held,

Sought to grasp the thought of

A young, lifeless body

Left lying on that hospital bed.

Swaddled by the night's rich darkness,

Full of chants, cries, and pains,

I am reminded that

Only what's done for Christ remains.

Tonight, as my gaze meets again this

African moon, from half a world away, I remember

The cries, the lost, this life,

The strange peace and the hope that

We will meet again.

What an oddly beautiful night it was to die.

So, take courage, dear heart

Don't fear the night, don't fear the pain,

Rest in His unchanging grace.

Go,

and be the hands

of the only Son who saves.

Peer Reviewed: Submitted 4 Sept 2021, accepted 19 Sept 2021, published 24 Dec 2021

Competing Interests: None declared.

December 2021. Christian Journal for Global Health 8(2) 
Acknowledgements: I wrote this poem after a five-week medical mission trip in the Democratic Republic of Congo summer 2021, between my first and second year of medical school. In this poem, I reflect on the death of a patient who accepted Christ on the operating table, just two days before his death. In this poem, I write about the process of accepting the patient's death and the hope that I found in the gospel. I pray this poem will inspire the reader to not shy away from the hardships that can come with medical missions but to fully embrace God's calling to be His hands and feet to bring the gospel to the ends of the earth. I also hope and pray that this poem will allow the reader to reflect on the gift of eternal life, and inspire him or her to use medicine as an avenue to share the gospel with others. This poem was written so that the reader will reflect on the beauty, the urgency and the power of the gospel.

Correspondence: Estelle Viaud-Murat. estellemvm@gmail.com

Cite this article as: Viaud-Murat E. I will never see a full moon the same. Christ J Global

Health. December 2021; 8(2):45-46. https://doi.org/10.15566/cjgh.v8i2.581

(C) Author. This is an open-access article distributed under the terms of the Creative Commons Attribution License, which permits unrestricted use, distribution, and reproduction in any medium, provided the original author and source are properly cited. To view a copy of the license, visit http://creativecommons.org/licenses/by/4.0/ 